\title{
Resistance to Rupture in the Self facing a School failure Experience: Case Study of an Adolescent
}

\author{
Resistencia a la ruptura en el Self al enfrentar una experiencia \\ de fracaso escolar \\ Resistência à ruptura no self frente a uma experiência de \\ fracasso escolar \\ Ramon Cerqueira Gomes* \\ Federal University of Bahia \\ Maria Virgínia Machado Dazzani** \\ Federal University of Bahia \\ Giuseppina Marsico ${ }^{* * *}$ \\ University of Salerno
}

Doi: http://dx.doi.org/10.12804/revistas.urosario.edu.co/apl/a.7878

\section{Abstract}

\begin{abstract}
This research aims at understanding the meanings related to the schooling experience of an adolescent at failure risk in a Brazilian Federal Institution of vocational education. We highlight what we call resistance to rupture since the participant did not experience an essential transformation of his predominant I-position (I-excellent student), even when he had to repeat the third year of the vocational high school. The theories that support this study are cultural psychology of semiotic dynamics and the dialogical self-theory. 'I-student' positions have
\end{abstract}

appeared obedient to parents' voices who believed in the school success of the participant and showed him directions to keep studying in the institution; nevertheless, other voices also interacted with him: peers' and teachers' who acted as relevant in the reconfiguration of his 'I-held-back-student' by silencing it. This silencing was a process of resistance to rupture-transition in the participant's self. His resistance to rupture-transition reduced tension within the self, and required less effort from the point of view of the dialogical reorganization of his psychological system; therefore, it possibly worked as a self-regulating process of the self.

\footnotetext{
* Address correspondence to Ramon Cerqueira Gomes. Federal University of Bahia. Federal Institute of Education, Science and Technology Baiano, Brazil. E-mail: ramon.gomes017@gmail.com

** Federal University of Bahia, Brazil.

*** University of Salerno, Italy. Federal University of Bahia, Brazil. Ideas for the Basic Education of the Future (International Centre of Excellence on Innovative Learning, Teaching Environments and Practices), Education Department of East China Normal University, Shanghái, China.
}

To cite this article: Gomes, C. R., Dazzani, M. M. V., Marsico, G. (2019). Resistance to Rupture in the Self Facing a School Failure Experience: Case Study of an Adolescent. Avances en Psicología Latinoamericana, 37(3), 407-420. Doi: http://dx.doi. org/10.12804/revistas.urosario.edu.co/apl/a.7878 
Keywords: Adolescents, narrative, self, schooling, resistance, rupture, transition.

\section{Resumen}

Esta investigación tiene como objetivo comprender los significados de la escolarización de un adolescente en una condición de fracaso escolar en una institución federal brasileña de educación vocacional. Se destacó lo que llamamos "resistencia a la ruptura en self", teniendo en cuenta el hecho de que el estudiante entrevistado no experimentó una transformación importante de su posición de I predominante: yo-excelente-estudiante, a pesar de que estaba repitiendo su tercer año de educación vocacional. Las teorías que apoyan este estudio son la psicología cultural con una base semiótica y la teoría del self dialógico. Las posiciones relacionadas con yo-estudiante han aparecido, muchas veces, sumisas a las voces de los padres que creían profundamente en el éxito escolar del participante y lo instruyeron para continuar en la institución, pero otras voces también interactuaban con su self: Compañeros y maestros que actuaron como voces relevantes en la reconfiguración de su yo-estudiante-repetitivo, poniéndolo en silencio Este silenciamiento del yo-estudiante-repetitivo se mostró un proceso de resistencia a la ruptura-transición en su self. Esta resistencia a la ruptura-transición redujo la tensión dentro del self y requirió menos esfuerzo desde el punto de vista de la reorganización dialógica del sistema psicológico, indicando, por tanto, un proceso de autorregulación del self.

Palabras clave: adolescentes, narrativa, self, escolarización, resistencia, ruptura, transición.

\section{Resumo}

Esta pesquisa tem como objetivo compreender os significados da escolarização de um adolescente em uma condição de fracasso escolar em uma instituição federal brasileira de educação vocacional. Destacou-se o que chamamos "resistência à ruptura em self", tendo em conta o fato de que o estudante entrevistado não experimentou uma transformação importante de sua posição de eu predominante: eu-excelente-estudante, apesar de que estava repetindo o seu terceiro ano de educação vocacional. As teorias que apoiam este estudo são a psicologia cultural com uma base semiótica e a teoria do self dialógico. As posições relacionadas com eu-estudante têm aparecido, muitas vezes, submissas às vozes dos pais que acreditam profundamente no sucesso escolar do participante e o instruíram para continuar na instituição, mas outras vozes também interatuavam com seu self. Colegas e professores que atuaram como vozes relevantes na reconfiguração de seu Eu-estudante-repetente, pondo-o em silêncio. Este silenciamento do eu-estudante-repetitivo se mostrou um processo de resistência à ruptura-transição em seu self. Esta resistência à ruptura-transição reduziu a tensão dentro do self e requereu menor esforço do ponto de vista da reorganização dialógica do sistema psicológico, indicando, portanto, um processo de auto-regulação do self.

Palabras clave: adolescentes, narrativa, self, escolarização, resistência, ruptura, transição.

Academic life is one of the most important dimensions in the development trajectory of a person. The investigation of the self in real contexts of formal education can improve our understanding of the psychological development of the student considering the dialogical dynamics established in the relationship with the institutional actors of the school and several contexts (family, neighborhood, peers and others). The dialogical processes within the self, according to Marsico and Tateo (2018a), and Zittoun (2006), mobilize the construction of the Self of those interacting within school contexts, especially students.

Academic experiences often present a number of challenges related to the development of social and cognitive skills: Grade transitions, teacher's changes, arrival of new classmates, new themes, and parent's involvement in the school life of 
children, among others. Students are, then, summoned to negotiate, in his/her self, such demands, which are produced from interactions established in educational contexts.

The construction of the self happens by means of a dialogic dynamics of I-positions through different voices coming from several actors in educational contexts. Understanding the constitution of the self in educational contexts involves the idea that, by participating in educational activities, students gradually internalize and appropriate signs, learning how to manage them in order to elaborate, regulate and reflect on themselves through the interactions and semiotic resources originated from formal educational experiences. The concept of Educational Self (Marsico \& Tateo, 2018b) is an attempt to capture this process by stressing how the discourse taking place in the educational context is providing the child with a complex repertoire of symbolic resources, namely, academic achievement, school rules, teachers and parents' voices about student performance, peer group culture and others which mobilize the definition of her own self. In this process the Self is working through these signs to produce meanings about herself, the others and the world.

Hermans, Kempen and Van Loon (1992) conceptualized the self in terms of a dynamic multiplicity of relatively autonomous I-positions. In this conception, the "I" has the possibility to move from one spatial position to another in accordance with changes in situation and time. The "I" fluctuates among different and even opposed positions, and has the capacity to imaginatively endow each position with a voice so that dialogical relations between positions can be established.

All these I-positions are associated with someone in some context, and function as a semiotic structure that allows the creation of responses/voices to this social other. If, for example, a student leaves a part-time school and goes to a full-time one, the I-student position already built into his/ her self will probably be challenged by the voices of the student's new peers, teachers and others participating of the new school life. As a result, when people enter different contexts, they need to deal with other positions or voices related to significant new social others, which may unbalance the continuity of the self by presenting other perspectives, new points of view and other time-space reference points (Gomes, 2018).

The process of education requires interactions between humans in relation with culturally constructed knowledge. They are mediated by semiotic means and artefacts, in specific social settings. It is expected that, through such interactions, a person will expand her capacity to think and act within or outside the educational setting in the present, or later in life. The process of education can occurs in settings which are institutionally designed as educational (e.g., the classroom) but also in other social settings (Hviid \& Zittoun, 2008).

The main objective of this article is to understand the meanings expressed in the narratives, along the schooling process, by a teenager in a situation of school failure in a federal institution of vocational education in Brazil. A case study is carried out, in which the dialogical character of the self is emphasized by prioritizing the self's need to solve those tensions present in the dialogic dynamic of several voices, both internal (I-student-excellent) and external (my mother, my teacher and so on).

\section{Conceptual references}

Cultural Psychology of Semiotic Dynamics is a theory that seeks explanatory models about the functioning of people in society. This theory explores the development of applicable, generalizable study methods, taking into account phenomena that occurs in the lifetime of human beings (Valsiner, 2007 ; 2014). This conception is consistent to the notion of Psychology as a plural field of knowledge with different perspectives about what people are, 
and how they function psychologically. For Valsiner (2017), every human psychological phenomenon - from basic sensations to complex aesthetic experiences - is PERSONAL (they are mine, not yours), UNIQUE (they occur now) and STRUCTURED (they constitute standards that can be well-structured, such as opinions, or quasi-structured, such as feelings about some event or object).

Valsiner (2007) states that the semiotic mediation system can be seen as a regulatory system of meanings, which guarantees psychological distancing from the here-and-now. People, in a given situation, consider the new problems that need to be addressed. To do so, they use the signs at hand.

According to Bruner (2003), we constantly build and rebuild our self to deal with the demands of the situations we face; and we do this as a kind of guide that is constituted from our memories, hopes and fears of the future. This phenomenon results in the stories we tell about ourselves, as well as those that are told about us.

The self is dependent of alterity, and constructed from the semiotic transactions culturally framed within concrete communicative practices in specific socio-institutional contexts; it concerns a practical-reflexive sense of oneself (Lopes de Oliveira, 2013). Regarding the schooling process, the person has to deal with several actors and institutional demands, which can produce tension in several I-positions within the self. These tensions incite possible processes of intra and inter-psychological changes in the personal dialogical dynamic.

According to Zittoun (2008), institutions are important contexts which likely facilitate, or constrain, personal reconfigurations. Firstly, they have cultural elements, which may become available symbolic resources in a given context. Secondly, to be actually used, these elements often need to be mediated by specific forms of relationships. Institutions, traditions and culture are understood as frames of specific semiotic webs, constituting the fabric of a thinking space. Traditions produce semiotic webs that are long lasting, and affect many people who have little power to change them. In contrast, the interpersonal relations are shaped by constant semiotic exchanges among people who can negotiate them.

The constitution of the Educational Self occurs in a dialogic dynamic of the I-positions that acts through different voices from the person's educational experience with different actors (Marsico \& Tateo, 2018b), with which one elaborates feelings, beliefs and attitudes related to experience. According to Marsico: "The construct of Educational Self, as a specific part of Self, emerging from the individual's experiences made by in the educational contexts, has been initially introduced" (2018, p.vi).

The Educational Self comprises a legacy of symbolic resources constructed from the knowledge, beliefs, narratives, and affective states established during the person's educational life. Understanding the Educational Self construct involves the notion that, during participation in school activities, the student progressively internalizes and appropriates signals, learning to administer them in order to elaborate, regulate, and reflect on the self(Iannaccone, Marsico, and Tateo, 2013).

\section{Dialogical Self Theory, responsiveness and catalysis in the I-positions}

According to Valsiner (2014), the dialogicity, inherent to human communication, facilitates the exchange of knowledge between individuals and, through narratives, one may have access to other' subjectivity, meanings and signs present in her history. The dialogue enables, therefore, the sharing of the symbolic world and construction of the Self within cultural contexts. Dialogicity allows for intrinsic communicative relations between psychological systems, and through such dialogues, the person builds her Self in interaction with others.

Dialogicity is conceived as the capacity to create and communicate social realities based on the multivocalized diversity of human interactions, emerged during the history of phylogenetic 
development of the human mind (Marková, 2006). From this perspective, the social other (someone referent), who relates in some way to a person in a given circumstance, is understood as an indispensable element in the analysis of human processes.

All human communication takes place from the tension that involves communicative participants. All social actions only occur if there are oppositions in tension (Marková, 2006). In the Dialogical Self Theory, for instance, divergent voices (I-disciplined student versus I- haughty student) often exist within the mind of the person within a polemic situation. In contrast to the notion of an individual self, the dialogic self is based on the assumption that there are many I-positions that can be occupied by the same person. The "I", in a position, can agree, disagree, understand, oppose, contradict, question, challenge and even ridicule an "I" in a different position (Hermans, 2001).

The notion of voice, inspired by Bakhtin's ideas, is related to the notion that thought, feeling and action are mutually interwoven into one articulated set that expresses, externalizes or manifests itself within the self. The voice expresses a point of view, a perspective, a positioning, an I-position (Mattos, 2013).

Emphasis on dialogicity was especially developed in the Dialogical Self Theory, which proposes a decentralized self, perceived as multivocal. The dialogical self involves a dynamics of multiple voices in the mind that leads to different positionings, I-positions. The voices intervene in the mind of the subject and in the minds of other people through dialogue. The notion of I-positions involves the conception of multiplicity of the self among different voices preserving, at the same time, coherence and unity. In this way, the self is involved in processes of positioning and repositioning (Hermans, 2014).

The dialogical self arises from the dialogue between different voices and the changes of positionings during the person's life, from such interactions (Hermans, 2001) and it can be understood as a dynamic multiplicity of relatively autonomous
I-positions in the society of mind. As in the larger society, these I-positions can receive a voice and address each other in a variety of ways. For example, as a son, I love my father and often look at the world like he does; however, as a politician, I tend to disagree with his conservative opinion. When I notice that I look at a social problem in the same way my father does, I disagree with myself and pose some critical questions to myself. Along these lines, I make clear to myself where I stand on a particular topic.

Whereas each I-position has autonomy and authorial capacity and, as a mini-society, the self is organized from a polyphonic reality, in which multiple internalized voices may come into conflict with each other in a dynamics that involve dominant or silencing performances. When I-positions are silenced, authorizing the monologism of only one position of the predominant "I", the repositioning of the self is hampered (Hermans, 2002), delimiting what we here consider as resistance to rupture in the self. In this case, an I-position assumes the leadership in the task of the self to respond to other voices, in a restraining responsiveness to the manifestation of other I-positions (Gomes, 2018)

Responsiveness is a concept derived from the theoretical perspective of Bakhtin and his Circle. According to the Bakhtinian perspective on communication: "Any understanding of living discourse $[\ldots]$ is inherently responsive. Any understanding is imbued with a response and necessarily causes it, in a way or another: the listener becomes the speaker" (Bakhtin, 1997, p. 291).

For Menegassi (2009), it is assumed as a prerogative the fact that once a word is addressed to another, one will always expect an answer. According to Bakhtin, "[...] from the outset, the speaker expects a response $[\ldots]$ an active responsive understanding. The whole statement is constructed, so to speak, in the expectation of finding such an answer". (1986, p. 94). Students play an active role in their training process, given the way in which they organize their 
dialogic dynamics to respond to the voices in their daily interactions, as their positions regarding the voices define who they really are.

The structuring of these responses related to other voices within the school can be understood as a fundamental condition for the construction of the Educational Self. Therefore, responsiveness to other voices may reveal various signs about the identity of the person under development within school contexts (Gomes, Dazzani \& Marsico, 2018). Self produces meanings in daily life and identity can be conceived as the meanings created by the self through the social contact. This identity (a frame of meanings) is inherently provisional, and this specific identity is neither permanent nor unchanging (De Souza, 2005).

It is also possible to identify, in this process of semiotic mediation, through voices, the semiotic catalysts that engender emerging differentiation of psychological processes. Depending on the contextual support of the semiotic catalyst, several semiotic regulators can be activated (or deactivated) to act directly in the I-positions and in their dialogues (Valsiner \& Cabell, 2012). The catalytic signs "prepare the psychological ground" in a way that contextual support is provided for semiotic regulation oriented towards the immediate future of the self in a certain perspective. For example, a Jew eats a piece of meat and delights with it in his/her mouth, but will experience nausea and guilt (internal emerging signs) when $\mathrm{s} /$ he realizes that it is pork (new sign in the environment). The knowledge that the meat is pork catalyzes the production of negative signs, such as nausea and guilt.

\section{Ruptures and transitions in the self}

When a certain conservative cycle ${ }^{1}$ in a psychological system is broken by a significant change in

Conservative cycle refers to the tendency of human being to keep the stability and the continuity od the human conduct in the I-Other-World relationship the system's relation to the environment, generating uncertainty or ambivalence - a rupture - the system must be reorganized or altered until a relative stability is found - the transition (Zittoun, 2007). System's ruptures can be understood as breaks in conservative cycles, which force the system to be restored according to a different hierarchical order. These ruptures, in turn, require processes of transition that produce significant changes (Zittoun, 2007), since restoration may occur on multiple levels (Zittoun, 2008).

Those changes can be analyzed in terms of quality, since they are related both to the person's well-being as well as to their suitability to the environment in which the person is inserted. Any change that leads to modifications shall be considered developmental; however, a change leading to alienation of the social world or of oneself, by limiting new changes, shall be considered non-developmental (Zittoun, 2008).

Ruptures are breaks in conservative psychological cycles that allow the person to reestablish one's self system in a different hierarchical order, and, for this reason, they cause tension and discomfort. Thus, all disruption implies the need for subsequent transitions to reorganize the conservative cycle into a new configuration, better suited to the new reality to be faced by the person's psychological system.

Ruptures and transitions represent an important part of the development of the

self; they are not only relevant for the person's positionings before the oscillations of life, but, they are also inevitable events. After all, overcoming ruptures demands deep and meaningful changes that act as catalysts for the emergence of new processes, ideas, ways of feeling, thinking and acting. The consequences of rupture experiences result in the reorganization of the self, referring to new positionings of the 'I', based on contextual demands.

Drawing from a dialogical and semiotic perspective on human experiences, in the next section we analyze the narratives of an adolescent on his experiences at school, focusing on the signs and 
the dialogical processes identified in the construction of his narrative. It is proved the way in which the dialogical interactions with significant people in life incite his narrative about himself within a personal perspective that dialogically resists to an experience of rupture in his self.

\section{Roberto's case study}

Roberto, the participant, signed a written consent to collaborate with the study, where he learned about the objectives, justification, procedures and ethical safeguards regarding the research and his voluntary participation.

Our interest in this article focuses upon those moments when Roberto ${ }^{2}$ showed a tendency to move away from the possibility of modifying/bifurcating his "I-excellent student" position in his narrative, which would result in a rupture-transition in his self.

At the time of his narrative about his failure experience, he had avoided elaborating narratives about instances of failing at school. According to Pontes (2013), such unexpected transitions, personally and socially, usually do not have sociocultural support, constituting as non-normative events. Therefore, the self, under such conditions, may face more difficulties with re-adaptation.

Considering the specificity of the student facing a non-normative event (unexpected transitions), the study falls within the perspective of idiographic research, focusing on the singularity of the phenomenon in its process: How the student reacts to this non-normative event of school failure. This understanding of the psychological phenomenon has important implications, especially for the methodology used and for data interpretation. This perspective is based on understanding that the object of psychology is idiographic, that is, that psychological processes in operation in a person are singular in the irreversible time (Valsiner, 2017).

The narratives of Roberto (a pseudonym to assure anonymity) come from the Master's Degree research of the first author.
For Valsiner (2017), psychology is a generalizing science based on historically unique events. Hence, it is necessary that methods addressed by researchers take into account the systemic and inter-subjective aspects of knowledge production. Emphasis needs to be on the creativity of the researcher in face of the phenomena $\mathrm{s} / \mathrm{he}$ investigates, and in the promotion of introspection by the research subjects, for they are self-reflexive participants.

\section{Participant}

Roberto is a male student attending to the third year of high school in Brazil. He had had insufficient academic performance in the year prior to the research. Roberto was 18 years-old when he participated in the research; he lived with his father, mother and a 15-year-old brother. The mother worked as a preschool teacher, and his father was a welder, but at the time of the interview, he was unemployed. Roberto did not want to study at that institution, but he was registered there due to his parents' will. He had failed the third grade of high school, and was repeating the same grade at a federal vocational school ${ }^{3}$ at the time of the study.

\section{Procedures}

Three narrative interviews were carried out with the participant, assuming that both interviewer and interviewee actively negotiated meanings in the process. In addition, a socio-demographic data form was filled out.

The narrative interview began with the presentation of visual stimuli, used as facilitators of the student's narratives. This type of stimulus is useful to illustrate, schematically, what the goals of the interviews are by means of images as suggestions

In Brazil a federal vocational school is a public institution of education where students can take a professional courses at several levels: high school, professional courses after high school, undergraduate and graduate courses. 
(Jovchelovitch and Bauer, 2002). They were six images of schools, children and adolescents at school contexts, and, the last one, was a picture of the entrance of the institution where he was studying. These images portrayed different characters such as teachers, peers, parents, for instance. In other words, they featured several possible actors in their own school life.

The narrative interview, according to the format proposed by Jovchelovitch and Bauer (2002), consists of the participant speaking freely about a topic, from a triggering issue. In the study, the participant received the stimulus to initiate his narrative, and was invited to observe the figures and think about them. When he signaled that he had already observed enough, the following question was posed: "Tell me about your career at school since you went to preschool up to the present moment. What memories do you keep from this period? Tell me everything you remember". Three interviews were carried out.

At the end of the first interview, the socio-demographic questionnaire was applied. At the second and third interviews, questions were posed to the student to clarify certain elements of his narrative, as well as to better understand the meanings produced about his academic life.

\section{Results and discussion}

Roberto, facing the school failure, experienced events that demanded decisions and rearrangements of I-positions. This happened as new responsibilities and tasks were provided by social institutions (school, family) in view of varied demands concerning present and future projections for his self.

Roberto was a well-known student among peers and teachers. He was the vice leader of his class, he participated in the meetings of the class council by presenting the assessments of the disciplines, teachers and class' achievement. In addition, he worked on other projects and events at school.
In Roberto's narrative, one can identify that his predominant I-Position was the 'I-excellent-student'. He said, "I've always been an excellent student, I've always had good marks [...] I've always moved on to the next grade, I've always gotten good marks. As I said, after my warning [in the first grade] my behavior has [improved]". As we will see, later in this paper, the I-excellent student played an important role in Roberto's narratives about his school experiences.

Among the interactions he established early in his school life, we noticed an emphasis on his relationship with his mother, who took care of his preparations to go to school, and who monitored his activities directly. We also noticed his emphasis on the behavioral evaluations carried out by his teacher. Roberto reported that his mother's monitoring of his agenda was important to him. His mother used to check out his teacher's evaluation of his behavior.

\section{Rupture-transition in the self in the second year of elementary school: The emergence of the 'I-excellent student'}

In narratives about his childhood, Roberto established a positive self-image supported by his mother - who closely monitored his conduct - and by his teacher. Although evaluation represented a potentially anxious situation for Roberto, involving his and mother's expectations, he considered maternal care as positive. The tension produced by the expected teacher's evaluation triggered a self-regulation mechanism that Roberto used to build his self-image, since he was afraid of possibly showing to his mother a negative assessment by the teacher.

Before the first year, Roberto evaluated himself as a difficult student in the classroom: "Like, being up to no good, talking, [...] fooling around, not paying attention". However, in the second year, an event reported by Roberto can be interpreted as a rupture-transition in his school trajectory. He 
said, "The image that comes to my mind is a just messing around, no physical fights, and the teacher arguing with me; she called the director who took me to a room, just the two of us".

According to him, in this occasion he was taken to the school board because of his undisciplined behavior in the classroom, and he ended up being warned. Subsequently, at home, Roberto was physically punished by his mother, and verbally punished by his father. This event outlined a bifurcation in his trajectory because, since then, he behaved differently at school, especially in relation to classroom discipline. Roberto mentioned that, at the weekends, he would meet with his teachers at church. There was, then, a sharing of religious, school, and family discourses and experiences that, at that moment, converged to disapprove his behaviors.

Roberto experienced tension in his self, especially in reference to his I-position 'I-messy student', since several significant others strongly disapproved this position. Because of this tension, he mobilized new signs (voices) and modified his dialogical self-configuration concerning school life. The earlier signs he had used to define himself - messy, inattentive, talkative - were, then, replaced by others, like, "After that, I became quiet", he said, referring to his behavior at school. In other excerpts, Roberto argued, “only after [...] that I came to have [...] such quieter behavior in the classroom", and, "my learning improved after I was warned".

Warnings by the teacher, the director and his father, as well as mother's physical punishment, led to a discontinuity in Roberto's self-system, through a rupture-transition, functioning as semiotic catalysts of changes in the field of his self, enabling the emergence of the "I-excellent student" position. It is also important to highlight that he studied (in previous years) in an evangelical school. So, Roberto's need to respond to mother, father, teacher, and director reveals the importance of replying to these people in his task to produce narratives about himself and his own life. This "I-excellent student" position then played a significant role for Roberto to reorganize his narrative in face of the tension coming from the school failure, because it allowed him to create a new perspective on his relationship with the school, promoting a new configuration of his self-system in time-space. The participant affirmed that he turned out to be an "excellent" student since then. He modified his perspective on his school experiences to answer to social others according to a new personal narrative as a disciplined and excellent student ('I-excellent student').

This bifurcation illustrates a self-regulating process, by means of the "excellent" sign, essential for the construction and consolidation of his Educational Self. It is important to point out that Roberto had reported that he almost faced a school failure in the sixth year (when he had to move out of town), and when he failed in the ninth year, due to problems in his relationship with a school teacher. However, these events did not decisively affect the stability of his 'I-excellent student' position in his present narrative. Although parents have a meaningful role in his schooling, at the end of high school, he had different social others allied to the 'I-excellent student' position: his teachers and peers. Consequently, this I-position gave Roberto greater autonomy and power with respect to academic matters, empowering him in relation to the voices of adults, especially, the voices of parents.

Likewise, he actively assumed the notion that he was "responsible" for his academic life. This produced new self-meanings about his experiences in the school context, with a view to signaling the need for greater autonomy to conduct his actions in this context.

I have been accompanied by my parents since I joined here. Whenever they could, they can, they come. Nowadays not so much, because I'm 18 and I'm going to turn 19 [years old]. So today I am responsible here for myself, it's me. 
[...] I see myself that way [...] now, as walking with my own steps, being responsible for my actions, being more responsible for myself, self-monitoring, not having to be obliged to do anything, but I really know what I have to do

Although he was attending, again, to the high school's third year, Roberto brought up, in his narrative, the 'I-responsible student', which coexisted in ambivalence with the 'I-in need-of-improving student'. Although he had a very good self-appraisal as student, his narrative showed two voices, A and B, in tension. Voice A expressed a good evaluation of himself as a student: he was applied and responsible. Voice B, though, expressed his need to improve his dedication regarding study's habits.

I see myself as an applied student, responsible (voice A), [...] I see that I need to improve in many things (voice B), to dedicate myself more to some subjects than to others, for I realize that I dedicate myself more to one subject than to another

Roberto showed a clear preference for meanings related to the maintenance of his 'I-excellent student' position, and, so, he did not bring any critical meanings in relation to this position. For instance, voices associated to the 'I-responsible student' referred to the idea of self-monitoring, so there was no decisive contradiction with the meanings he produced about being an excellent student: 'I've always moved on to the next grade, I've always gotten good marks." Nevertheless, this meaning of "excellence" was in important opposition to his situation at the time of the interviews, which took place while he was repeating the same grade. When asked about why he failed, he said, "I do not know". It was a clear avoidance of the topic that, at the moment, was too destabilizing for his self, and contrary to the voice of the 'I-excellent student' position. Therefore, the position of 'I-repeater student' was silenced by the 'I-excellent student' position.

\section{Resistance to rupture-transition in the self: maintenance of the dominant position through coalitions with other significant social groups}

The failure in the high school's third year was experienced intensely, mobilizing his parents' actions and, temporarily, destabilizing his 'I-excellent student' position. Parents' actions in face of the disruptive event (failure) redefined Roberto's trajectory, since he was determined to quit school, enroll in a kind of online-learning course to complete high school and become able to work. His parents' interventions, however, were decisive for Roberto's life trajectory, because they imposed on him to go back to school.

At first, Roberto reacted aggressively, justifying his anger as a result of parents' imposition. Then, he acquiesced to his parents, after negotiating with them. When classes began, Roberto reconsidered his parents' attitude by saying that, then, he could understand that option was "the best" for him. It is, therefore, possible to see that the value positively attributed to his parents in his trajectory, significantly reappears and his parents' imposition semiotically emerges as legitimate, in detriment of his decision to quit school. He qualifies his parent's choice as "better" than his own. This empowerment of parental voices occurs at a time of destabilization of the 'I-excellent student', weakened by the experienced failure. Parents, as significant others in the self, therefore, gain space due to the tension experienced by Roberto related to his dominant position.

Regarding the repetition of the school year, Roberto mentioned negative expectations about possible voices that would emerge in the new context, considering that he had lost ties with old peers and teachers, with whom he had close relationships. For instance, they could judge him because of his failure: "And then I came, initially having a fear of starting it over, how people would look at me (emphasis added), how that new start would be". 
In face of fear of others' judgments, Roberto emphasized those voices and positions that aligned with the promoter sign "excellent student", particularly the 'I-excellent student' position. New teachers and peers, though, put him in a valued position in class, and this contributed to his return to the earlier position. Therefore, Roberto rejected experiencing a rupture-transition in his self, and did that by the reactivation of his 'I-excellent student' position. The voices from both educational and family contexts (mother, father) delivered messages that allowed him to reposition himself as a valued student.

Roberto's parents forced him to study again at school, and believed in his success. Similarly, teachers and peers behaved and sent friendly messages to him that did not match his fears (like, he would be treated as a bad student due to his failure to move on to the next grade). Tensions within the self, then, became lower when significant others offered him support and attention, which enabled him to keep his narrative about facing a possible rupture.

Today it is nice, I have already adapted to the room, the class, a very cool class; teachers do not even look at me with that thing, they are always supportive, giving me support, not looking like "Wow, you failed". On the contrary, I get support and everything, as they've always given me and I think they've even doubled this support and their attention to me.

For Menegassi (2009), the inner discourse is based on the relationship with others and results from the internalization and reconstruction, from a personal perspective, of those social practices in which the subject participates throughout his/her existence. In Roberto's case, he had several flags in the environment that could have led him to an experience of rupture-transition: school failure, parents' imposition to continue attending to school against his will, the loss of ties with peers, and the frustration of his plans (he intended to study History or Theology that year). However, Roberto rejected the rupture in his self, and maintained his
'I-excellent student' position, what protected the dialogical system from a break (rupture).

It can be said that Roberto experienced a situation in which he silenced possible negative voices (from his failure), and kept his I-position in the school context as an "excellent" student, which, to us, seemed somehow surprising. However, according to Prokopiou, Cline and de Abreu (2012), individuals construct hibernated or silenced identity's positions as a resource for rapid change to cope with uncertainty. In this case, Roberto's failure was completely unexpected both by himself and by his family, and generated uncertainties about his academic life that made it possible to silence new voices, leading the self to produce a kind of monologic narrative.

In his relationship with his mother and social others, such as peers and teachers, Roberto expressed a certain responsiveness that pointed to his coalition with maternal and social others' expectations in relation to his academic success. This, in turn, contributed to his 'I-excellent student' position, which subsisted even after the experience of failure. By responding to his mother's internalized voice, Roberto struggled to build a narrative of continuity of his previous I-position. Coalitions with other voices were also made (teachers' and peers'), softening the tensions in his self caused by the school failure. This offered dialogical perspectives that made it possible for Roberto to respond to the voices of other significant social ones with the 'I-excellent student' position.

\section{Final remarks}

Students often need to deal with developmental transitions that trigger important changes in their lives. The objective of this article was to understand, from a dialogical perspective, the meanings manifested by a teenager who had experienced a situation of failure while studying in a vocational education institute, in terms of his I-positions related to his schooling process. 
In order to clarify the analytical perspective of the investigated case, it is necessary to consider that: (1) the Educational Self is interwoven with other significant voices beyond the parents' ones (Marsico \& Iannaccone, 2012, Marsico, Iannaccone \& Tateo, 2013, Marsico \& Tateo, 2018a); (2) the dialogical self is defined by its social feature, that is, by the intersubjective interchange and social domination found in its processes (Hermans, 2002); and (3) the systemic nature of the self, which is not an entity but a relation process that constitutes the interface between the psyche and the environtment (Valsiner, 2014).

In Roberto's narrative, he said, 'I've always been an excellent student". It is noticeable that he softened the difficulties experienced throughout his academic life, mentioning them, only, as unpleasant facts not related to the quality of his role as student. His 'I-excellent student' position acted responsively to significant voices in his self: mother, peers, and teachers, which functioned as relevant voices in the reactivation of the 'I-excellent student' position after his school failure. In this way, Roberto silenced the positioning 'I-repeater student', and rejected experiencing a rupture-transition in his self system, doing this through the protection of the 'I-excellent student' that was also supported by the voices of significant social others, as mother, peers and teachers.

The development of the self occurs according to transitions of identity that unfold as the person experiences possible new positions, for instance in the school context (Hviid \& Zittoun, 2008). According to the dialogical self theory, the 'I' floats between different, and even opposite, positions, and has the ability to endow each position with a voice, so that dialogical relations between positions can take place (Hermans, 2002). In the present case, the main voice in Roberto's self exerted a strong dialogic power over the others, even in face of an imminently destabilizing situation -his school failure -which could be, at first, attributed to his bad performance.
Roberto's responsiveness to other meanings authorized the configuration of his self according to the continuity of the 'I-excellent student' position. As Gomes and Dazzani (2018) explain, responsiveness is a necessary condition to dialogical human beings. We always need to respond someway to others -be they concrete or imaginary - in order to express who we are, or hope to be.

To resist a possible rupture-transition in the self, through keeping his 'I-excellent student' position, Roberto persisted in producing positive meanings about himself as a student, which limited the power of other voices that negatively judged his school failure condition. He openly acknowledged his difficult moments at school, and did not hide critical facts or his schooling problems. However, this acknowledgement was not sufficient to modify his dominant I-position. The dialogic processes involved in Roberto's case characterize, therefore, what we call here resistance to rupture-transition in the self, which protects the continuity of the dialogical self-system. In his case, this was also possible through his responsiveness to other significant social others.

Although the self is open and emergent (Valsiner, 2017), we find, in this case, a narrative construction that points to the semiotic work of the self in protecting the system from continuous changes that could make human psychological experience very disorganized, without dominant signs. In this study, a bigger voice, 'I-excellent student', has the power of controlling the exchange of others positions within the self. Thus, the system has less chance of being ruptured. This position responds mostly in the self through its powerful dialogical position.

Therefore, in facing a tension, the self will search the way to increase its stability through the semiotic exchange among several voices/positions. Commonly, this can occur through the 1) ruptures-transitions: when the person does not have sufficient semiotic resources/voices to stabilize the system which breaks itself to produce novelty, and 2) resistance to rupture-transition: 
when the person looks for semiotic resources/ voices available in the dialogic system in order to decrease the tension and protect the system from breakage. The resistance to rupture-transition requires a minimum dialogical reorganization of the psychological system and, therefore, indicates to be a self-regulating process of the self.

\section{References}

Bakhtin, M. (1986). Speech genres and other late essays. Austin, TX: University of Texas Press.

Bakhtin, M. (1997). Estética da criação verbal. São Paulo: Martins Fontes.

Bruner, J. S. (2003). Making stories: Law, literature, life. Cambridge, MA: Harvard University Press.

Gomes, R. C. (2018). Regulação semiótica no self educacional de adolescentes na transição para o ensino médio profissionalizante: a atuação da exotopia dentre as posições do eu. Instituto de Psicologia. (Tese de doutorado, Universidade Federal da Bahia, Salvador-BA).

Gomes, R. C., \& Dazzani, M.V.M. (2018). Exotopic Processes in Emergency of New Positions in Self. Human Arenas k(2), 191-197. Doi: https:// doi.org/10.1007/s42087-018-0005-y

Gomes, R., Dazzani, V., \& Marsico, G. (2018). The role of responsiveness within the self in transitions to university. Culture \& Psychology, 24(1), 49-59. Doi: 10.1177/1354067X17713928

Hermans, H. J. M. (2001). The Dialogical Self: Toward a theory of personal and cultural positioning. Culture \& Psychology, 7(3), 243-281.

Hermans, H. J. M. (2002). The dialogical self as a society of mind: an introduction. Theory and Psychology, 12(2), 147-160.

Hermans, H. (2014). Self as a Society of I-Positions: A Dialogical Approach to Counseling. The Journal of Humanistic Counseling, 53(2), 134-159.

Hviid, P., \& Zittoun, T. (2008). Transitions in the process of education. European Journal of Psychology of Education, 23(2), 121-130.
Iannaccone, A., Marsico, G., \& Tateo, L. (2013). Educational self: A fruitful idea? In M. Beatrice Ligorio and M. César (Eds.), Interplays between dialogical learning and dialogical self (p. 219252). Charlotte, N.C.: Information Age Publishing.

Jovchelovitch, S., \& Bauer, M. W. (2012). Entrevista narrativa. Pesquisa qualitativa com texto, imagem e som. 90-113.

Lopes De Oliveira, M. C. S. (2013). The Bakhtinian self and beyond: Towards a dialogical phenomenology of the self. Culture \& Psychology, 19(2) 259-272.

Marsico G. (2018). Cultivating new ideas in cultural psychology of education. In G. Marsico \& L. Tateo, (Eds.). The emergence of self in educational contexts. Theoretical and empirical explorations, cultural psychology of education, 8, (pp. v-vii). Cham, Switzerland: Springer.

Marsico, G., \& Iannaccone A. (2012). The work of schooling. In J. Valsiner (Eds). Oxford handbook of culture and psychology (p. 830-868). New York: Oxford University Press.

Marsico, G., \& Tateo., L. (Eds.), (2018a). The emergence of self in the educational contexts. Cultural psychology of education. Cham, Switzerland: Springer.

Marsico, G., \& Tateo, L. (2018b). Introduction: The construct of educational self. In G. Marsico and L. Tateo, (Eds.). The emergence of self in educational contexts. Theoretical and empirical explorations, cultural psychology of education (pp. 1-14). Cham, Switzerland: Springer.

Mattos, E. de (2013). Desenvolvimento do self na transição para a vida adulta: um estudo longitudinal com jovens baianos. (Tese de doutorado, Universidade Federal da Bahia, Salvador, Brasil).

Menegassi, R. J. (2009). Aspectos da responsividade na interação verbal. Revista Línguas e Letras, 10(18), 147-170.

Pontes, V. V. (2013). Building continuity in face of sequent ruptures: Semiotic strategies of dynamic self-repairing. (Tese de Doutorado, Universidade Federal da Bahia, Salvador/BA). 
Prokopiou, E., Cline, T., \& de Abreu, G. (2012). "Silent" monologues, "loud" dialogues and the emergence of hibernated I-positions in the negotiation of multi voiced cultural identities, Culture \& Psychology, 18(4), 52-67.

Shooter, J. (1993). Cultural politics of everyday life: social contrutionism, rethoric and knowin of the third kind. Buckinghan: Open University Press.

Valsiner, J. (2007). Culture in Minds and Societies. Foundations of Cultural Psychology. LA/New Delhi: Sage.

Valsiner, J. (2014). An invitation to cultural psychology. London: Sage.

Valsiner, J. (2017). From methodology to methods in human psychology. Aalborg: Springer Briefs in Psychology.
Valsiner, J., \& Cabell, K. (2012). Self-making through synthesis: Extending dialogical self theory. In H. J.M. Hermans \& T. Gieser (Eds.) Handbook of dialogical self theory (pp. 82-97). New York: Cambridge University Press.

Zittoun, T. (2006). Transitions: development through symbolic resources. Charlotte, NC: Information Age Publishing.

Zittoun, T. (2007). Dynamics of interiority: Ruptures and transitions in self-development. In L. M. Simão \& J. Valsiner (Eds.), Otherness in question: Labyrinths of the self (pp. 187-214). Charlotte, NC: Information Age Publishing.

Zittoun, T. (2008). Learning through transitions: The role of institutions. European Journal of Psychology of Education, 23(2), 165-181. 